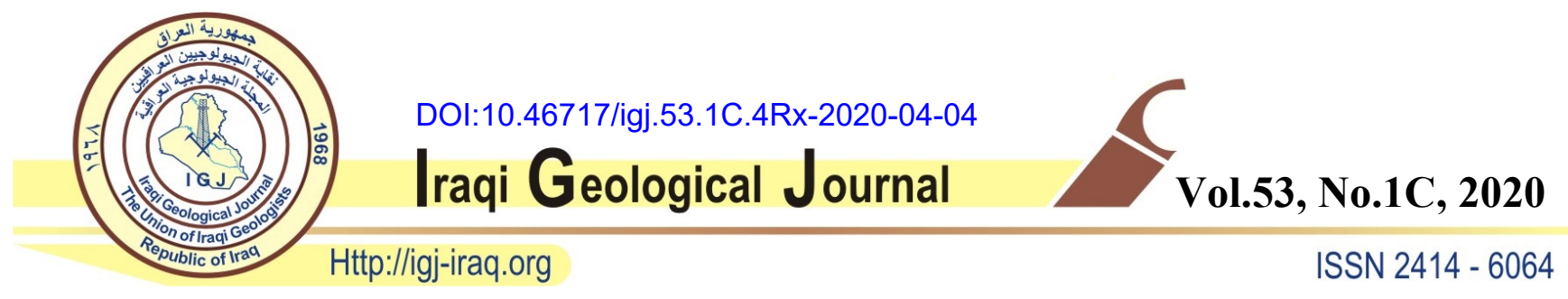

\title{
LATE CAMPANIAN-MAASTRICHIAN GASTROPODA FROM BEKHME FORMATION, NORTHERN IRAQ
}

\author{
Salam Ismail Al-Dulaimi \\ Department of Geology, Collage of Science, University of Baghdad, Baghdad, Iraq \\ E-mail: salamgeo2018@gmail.com
}

Received: 8 December 2019; accepted: 26 January 2020

\begin{abstract}
The gastropod fauna of the Upper Campanian-Masstrichtian Bekhme Formation in the Northern Iraq comprises six species belonging to six genera, six families are documented for the first time from Iraq. The species are abundant at the lower and middle parts in the formation. Most of the specimens are internal molds, some of which are, in addition in complete. The geographic distribution of the identified species is having closely affinity to the Tethyan fauna from Asia, Europa and Africa. These species are associated with large foraminifera such as: Orbitoides media; O.apiculatus; Loftusia elongatea; Omphalocyclus macroporus; Siderolites calcitropodes and rudist as: Durania cornupastoris, Hippurites sp.; Dictyptchus sp.
\end{abstract}

Keywords: Bekhme; Gastropods; Iraq; Maastrichtian; Rudist

\section{INTRODUCTION}

Bekhme Formation represents a carbonate succession that belongs to the Upper Cretaceous sequence of Iraq. The formation was deposited during the Upper Campanian- Masstrichtian cycle, which began with a widespread transgression and almost affecting Iraq after the end of the unrest caused by the Middle Cretaceous orogeneses. The rocks of Bekhme Formation outcrops in the High Folded Zone, and forms the interiors of many anticlines in the S and SW parts of the same zone (Jassim and Goff, 2006).

The stratigraphic and sedimentologic studies are available for Bekhme Formation in many locations of northern Iraq (e.g., Dunnigton, 1947; Bolton, 1958; Chatton and Hart, 1961; Yassin, 1973; Al Karadakhy, 1989; Ameen and Karim, 2008; Al Metwali et al., 2008; Dalshad, 2010; Al Obaidy R.A., 2016; Al-Dulaimi and Al Obaidy, 2017). However, the paleontological studies 
related to this formation are limited. The aim of the present study is to describe and identify the gastropod fossils of Bekhme Formation for the first time.

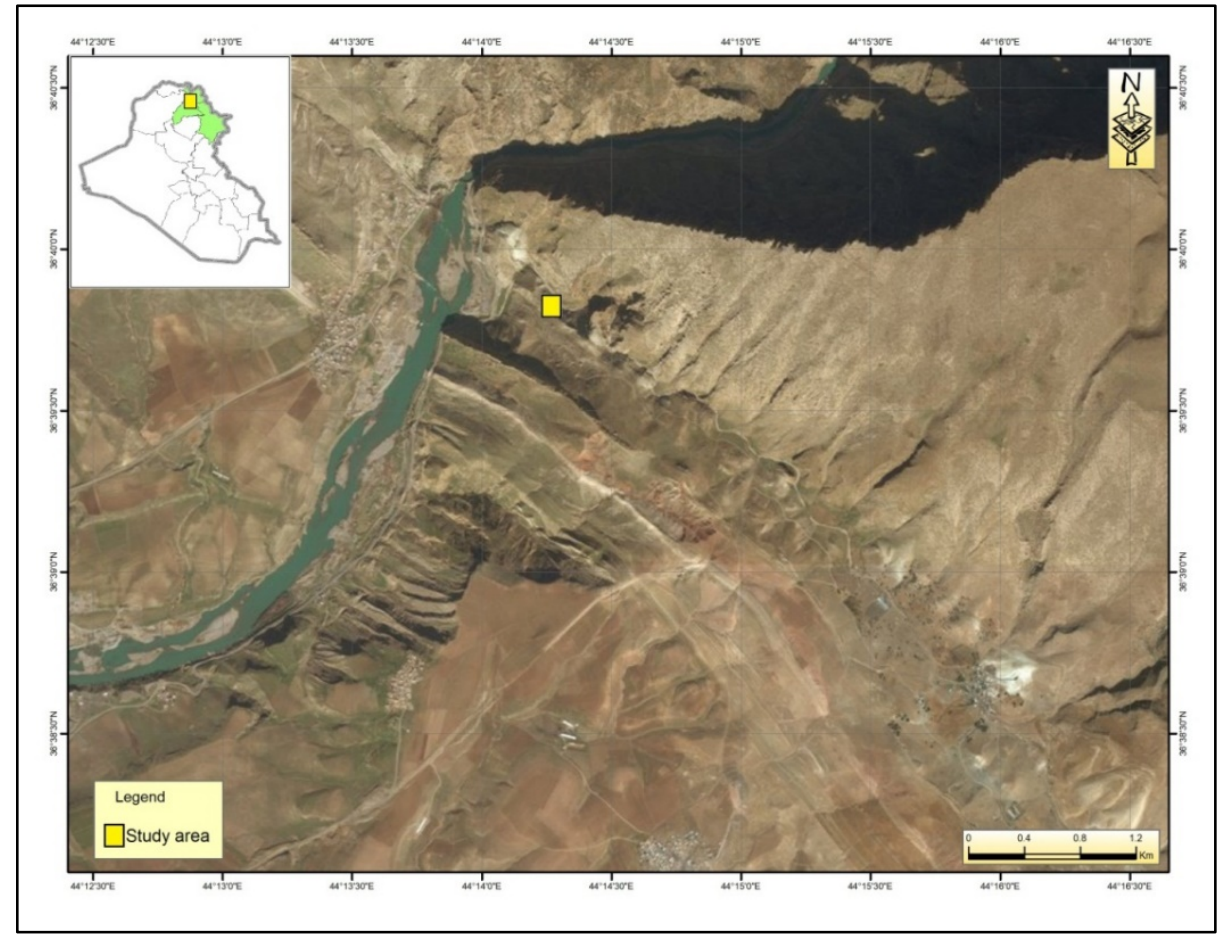

Fig. 1. Satellite image showing the location of the study area (Bekhme Gorge section) in Northern Iraq

\section{STRATIGRAPHY OF THE STUDY SECTION}

The type section of Bekhme Formation was described by Wetzel in 1950 from the Bekhme Gorge of the Greater Zab River in the High Folded Zone. At this type section, Bekhme Formation consists of dolomite, organic and reef detrital limestone, shoal limestone, and basal breccia conglomerate (Jassim and Goff, 2006). In this study, the succession of Bekhme Formation is selected from the southern limb of Harir anticline (Fig. 1) at the following coordinates, E $44^{\circ}$ 1416an N $36^{\circ}$ 3950. The succession shows a conformable upper contact with Shiranish Formation, whereas the lower contact is unconformable with Qamchuqa Formation. The thickness of Bekhme Formation is $321 \mathrm{~m}$ and it is built up of the following units (Fig. 2):

- Unit (A): Basal conglomerate 1- $18 \mathrm{~m}$. It comprises thick and thin bedded dolomitic conglomerate.

- Unit (B): The thickness of this unit is $24 \mathrm{~m}$. The bedding is continuous and parallel with few embedded calcarenite limestone. It consists of rudist, gastropods, algae and benthic foraminifera. 
- Unit (C): Thickness of this unit is about $75 \mathrm{~m}$. It consists of thick beds of grey dolomite interbedded with thin beds of coarse calcarenits, calcisitite and calculitite. The fossils of this unit include rudist bivalves, gastropoda, alge and large foraminifera.

- Unit (D): Massive, bituminous, recrystallized limestone and dolomitic limestone, dark grey color to yellow in weathered surface. The fossil of this unit includes rudist fragments and algae. It is about $204 \mathrm{~m}$ thickness.

Aqra and Bekhme formations were deposited mostly in reef and forereef environments, and the deposition took place along a carbonate ramp (Jassim and Goff, 2006).

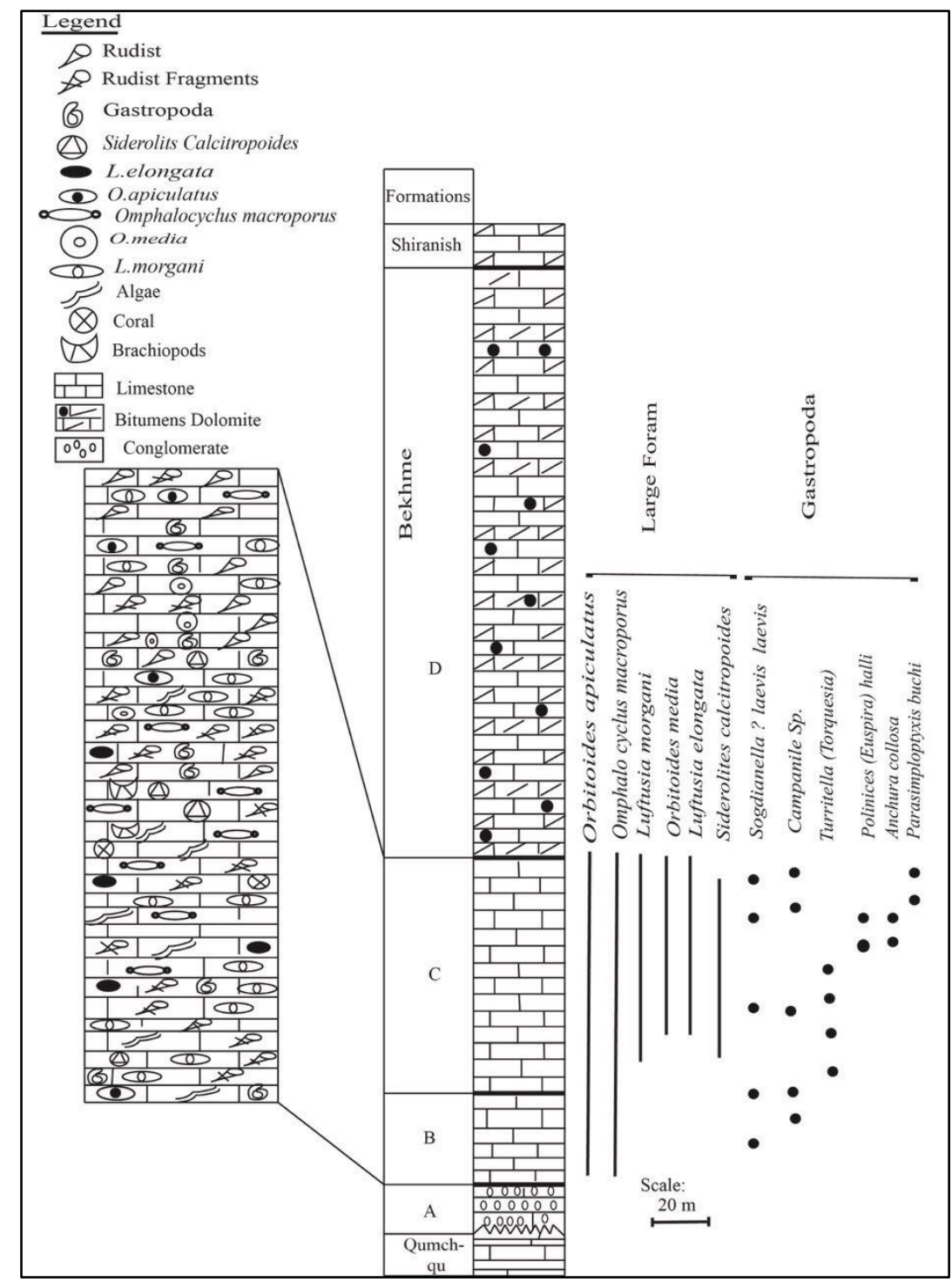

Fig. 2. Lithostratigraphy and biostratigraphy of Bekhme Formation at Bekhme Gorge section 


\section{SYSTEMATIC PALEONTOLOGY}

The specimens of this study are housed in the Department of Geology, College of ScienceUniversity of Baghdad. The classification followed here is that of Bouchet and Rocroi (2005). The terminology for description of gastropod used the glossary of Cox (1960) in the Treatise on invertebrate palaeontology, part 1 (Gastropoda).

Yin et al. (1963) divided the gastropod specimens based on the size into:

Small $(<1.0) \mathrm{cm}$

Moderately small (1.0- 1.5$) \mathrm{cm}$

Medium (1.5-2.0) cm

Moderately large $(2.0-2.5) \mathrm{cm}$

Large $(>2.5) \mathrm{cm}$.

And they classified the spire into:

Low- spired (pleural angle $>110$ )

Moderately low- spired (angle 90- 110)

Moderately high- spired (angle 50- 90)

High- spired (angle $<50$ )

The measurements are given in centimeters for their parameters as follow:

H: height

D: maximum diameter

HA: height of aperture

WA: width of aperture

HL: height of last whorl

PA: pleural angle

NW: number of whorl

$\mathrm{n}$ : number of specimens

nw: number of axial ribs

Class Gastropoda Cuvie, 1797

Clade Vetigastropoda Salvini Plawen, 1980

Superfamily Gampaniloidea Doville, 1904

Family Campanilidae Doville, 1904.

Genus Campanile Bayle (in Fischer, 1884) 
Remarks: Many fossil species ascribable to the genus Campanile Bayle in P. Fisher 1884, and have been suggested under the general Cerithium Bruguiere 1792, Potamides Brongniart, 1810, Telescopiu? Montfort, 1810 and Nerinea Defrance, 1825 (Matsubara 2009: 285 in Ayoub Hannaa and Fursich, 2011). However, no comprehensive taxonomic studies have been performed (Wagih and Franz, 2011). For example, previous researchers classified Campanile as Cerithiid (Lamarck, 1804; Cossmann, 1906 and Wenz, 1938) due to resemblance of shell ornament and shape. Wenz (1983) integrated Campanile and Plesiotrochus Fischer, 1878 among a few other questionable genera in the subfamily Campanilinae Douville, 1904 in the Cerithiidae. Delpey (1939), however, considers Campanile to be a descendant of Nerinea Deshayes, 1877 due to the appearance of the columellar folds. According to Kiel et al. (2000: 17), the genus Campanile has turriform shell and its whorls are ornamented with a wide tuberculate substural collar, spiral cords which may be beaded, and overlies fine engrave striae (Ayoub Hannaa and Fursich, 2011). In addition, columellar and parietal fold may appear and the ornament may vary on the last whorl. Delpey (1939) indicated that the longitudinal whorl section of the genus Campanile is defined by a medium parietal fold with two columellar fold. These specimens are classified as Campanile due to their turriculate outline convex whorls with deep sutures lines, and small columellar folds and deeper parietal fold. The taxonomic details of the genus Campanile are described by Houbrich (1981, 1989), Kell et al, (2000) and Matsubara (2009).

\section{Campanile sp. (Ayoub-Hannaa and Fursich, 2011)}

Material and occurrence: Four inner molds from the middle part of the Aqra Formation (Upper Campanian- Masstrichitian).

Description: Large size, turriculate, and highly conical, spire long consisting 7-10 overlapping whorls and forming about $70 \%$ of the total height. Whorls are strongly convex and separated by moderately deep sutures and gradually decreasing toward the apex, and the base is nearly flat. Diameter of specimens increases gradually from the apex to the aperture. Apex and ornamentation are commonly poorly preserved. The longitudinal whorl section has two small columellar folds (c1 and c2) with medium and slightly deep parietal fold (p) (Fig. 3).

Discussion: The specimens in this study are preserved as incomplete internal mould, and it is similar to Campanile genesh (Noetling which has been figured for example by Greco (1916: 121 (63) pl. 15 (7), fig 10, 11) and Elqat (2006: 98, pl.? figs 12, 14) from upper CenomanianMasstrichtian of Egypt and by collagens 1971: 17(159); pl. C, fig 5) from Algeria, (AyoubHannaa and Fursich2011), and by Ayoub-Hannaa and Fursich (2011) from Cenomanian- 
Turonian from Egypt. The longitudinal section of C. (C.) bussoni of Albanesi and Busson (1974) from Algeria and Cerithium sp (cf) in auguratum stoliczka of Quaas (1902) from Egypt and Ayoub-Hannaa and Fursich (2011) from Egypt, is intimately similar to the longitudinal whorl section of the current study specimens. Morphologically the specimen of the present study differs in having longer spire with 7-10 overlapping convex whorls from the specimens of other studies.

Table 1. Dimensions (in cm) of Campanile sp

\begin{tabular}{|l|l|l|l|l|l|l|l|l|l|l|}
\hline n.4 & $\mathrm{H}$ & $\mathrm{D}$ & $\mathrm{HL}$ & $\mathrm{HA}$ & $\mathrm{WA}$ & $\mathrm{PA}^{\circ}$ & $\mathrm{NW}$ & $\mathrm{D} / \mathrm{H}$ & $\mathrm{HL} / \mathrm{HA}$ & $\mathrm{WA} / \mathrm{HA}$ \\
\hline Range & $9.5-15$ & $3.5-7.5$ & $3-4.5$ & $3-3.5$ & $2-2.8$ & $35-40$ & $8-10$ & $0.36-0.58$ & $0.31-0.35$ & $0.66-0.8$ \\
\hline Mean & 12.25 & 5.5 & 3.75 & 3.25 & 2.4 & 37.5 & 9 & 0.47 & $0-33$ & 0.73 \\
\hline
\end{tabular}

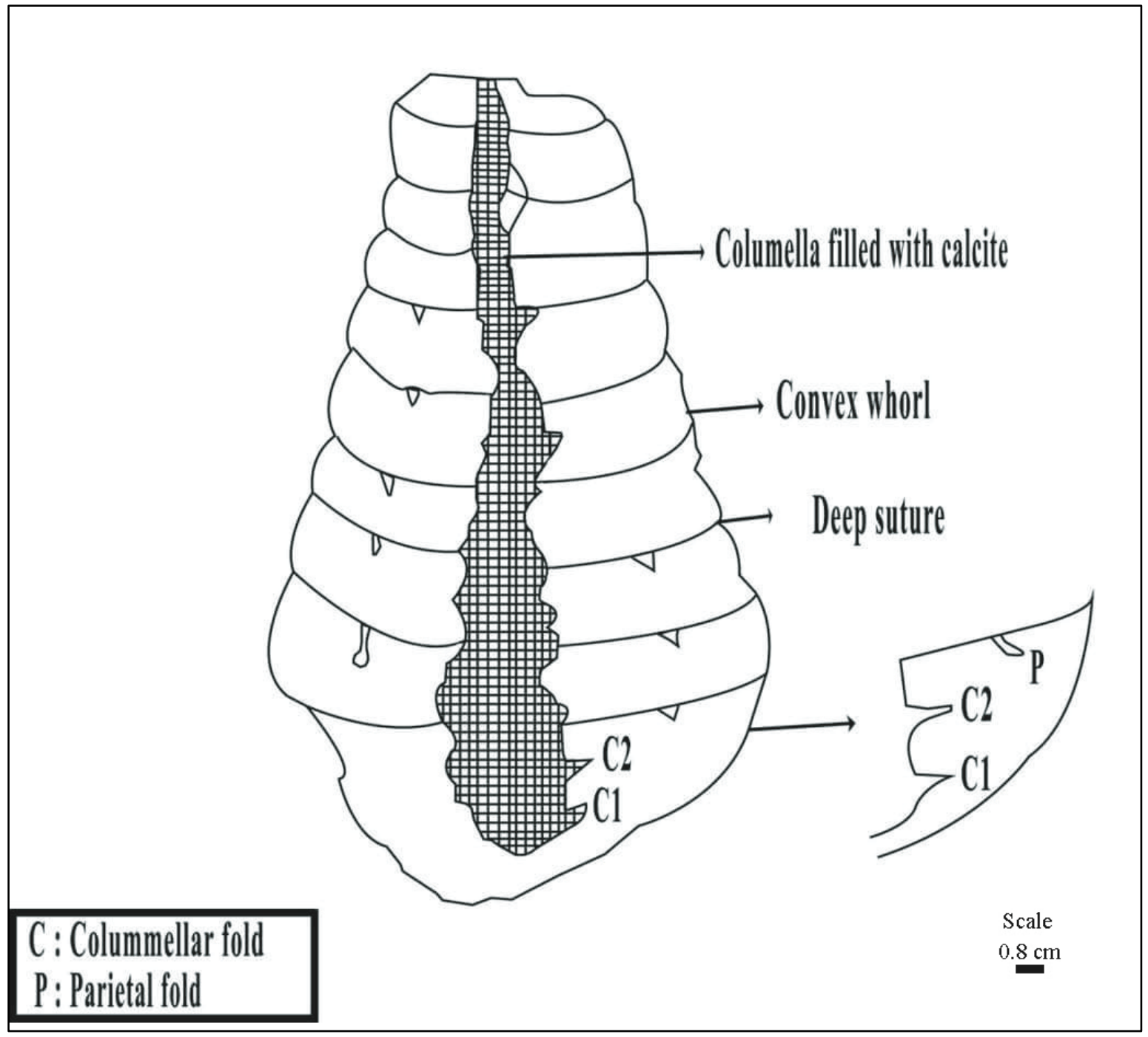

Fig. 3. 4Axial whorl sections showing the whorl folds 


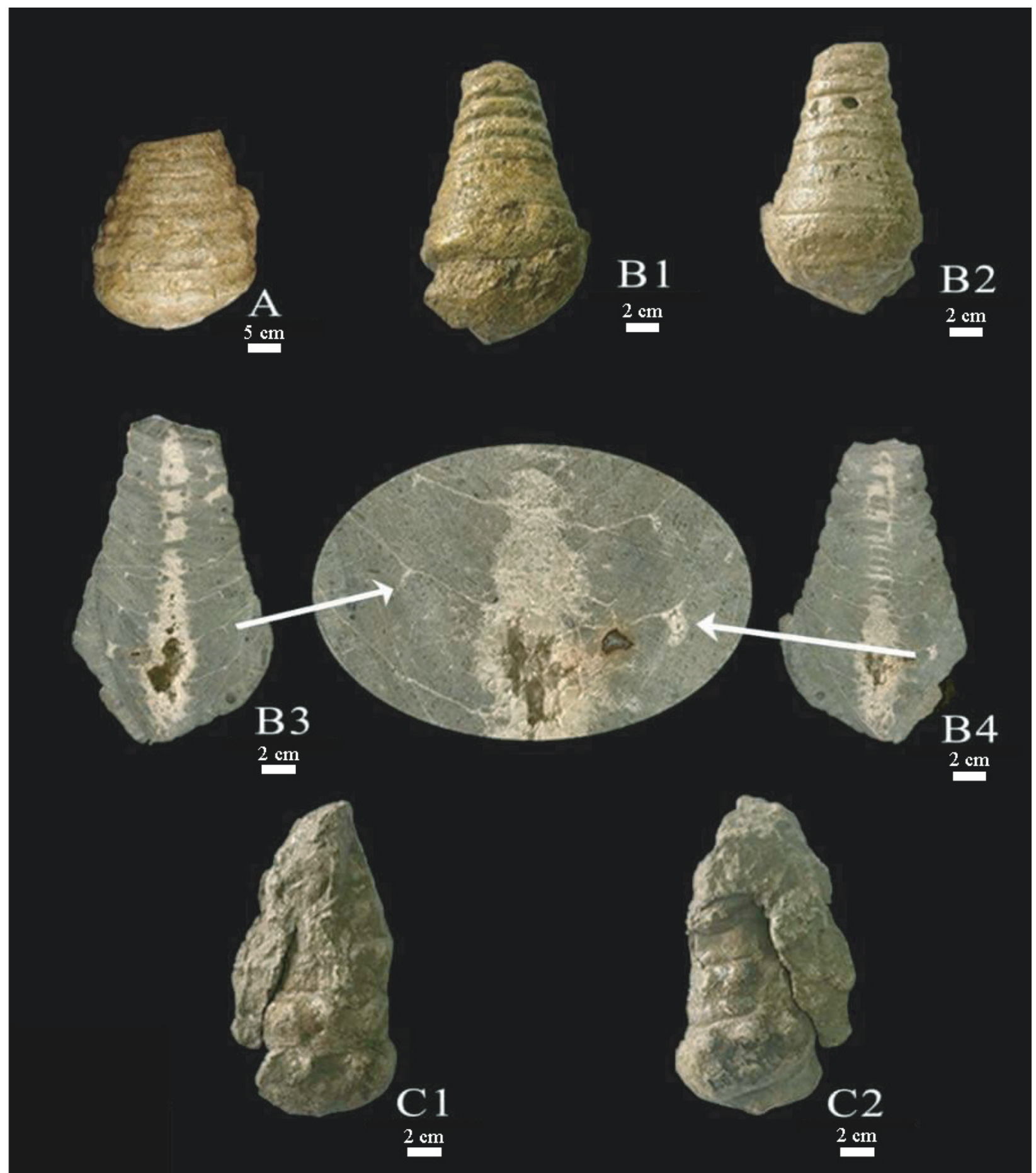

Plate 1. Internal mold of Campanile sp. from the Late Campanian- Masstrichtian of Bekhme Formation. $A, B_{1}$ and $B_{2}, C_{1}$ and $C_{2}$ are longitudinal view. $B_{3}, B_{4}$ axial whorl sections showing the whorl folds (arrowed) 


\section{Gastropods-Rudist Facies}

Kiel (2000) recorded the Late Cretaceous species of Campanile that are known from tropical Tethyan waters from India to Gulf of Mexico and thus show a distribution similar to that of Otostoma except for its absence from eastern pacific (Kiel et al, 2000). The recent Campanile symbolicum live in the shallow subtidal zone (Houbrick, 1989). The same habitat has been documented for Eocene Campanile and it is assumed for the Cretaceous species as well (Kiel et al, 2000). Mathias et al (2012) recorded ten species from the Thanetian of Kolosh Formation Northern Iraq, like the habitat of above species of Campanile.

Four groups of gastropods are considered as typical representatives for circum-equatorial rudist facies: the Nerineoidea, Pileolus, Discotectus, and the Acteonellidae. In previous reconstruction of Late Cretaceous gastropods biogeography, these gastropods of rudist facies have been considered as tropical gastropods (Sohl, 1971, 1987 in Steffen Kiel, 2015).

In this study, Campanile sp. belongs to gastropods-rudist facies because it is associated with different species of rudist as: Durania cornupastoris (Plate.2, Fig.D); Hippurites sp. (Plate.2, Figs.B and C); Dictyoptychus sp., and associated with large Foraminifera as follow: Orbitoids medius; Loftusia elongate (Plate.3, Figs.C and D); Orbitoids apiculatus; Omphalocyclus macroporus; Siderolites calcitroides with the occurrence of Actonilidae , Brachiopoda (Plate.2, Fig. A) and algae.

\section{Family Naicida}

Genus Polinices Montfort

Polinices (Euspira) halli (Gabb)

(Plate.3; figs.A-C ;Table.2)

- 1860. Lunatia halli Aced Nat. Sciphiladeli Jour., zdser., Vol. 4. P.68, Fig. 11.

- 1864. Lunatia halli. Meek, check list of Invertebrate fossils of North America, Cretaceous and Jurassic p. 20.

- $\quad$ 1868. Lunatia halli. Conrad in cook, Geology of New Jersey, p 729.

- 1892. Lunatia halli. Whitfield, U. S. Geol. Survey Mon. 18, p.130, pl. 15, figs. 13-16.

- 1905. Lunatia halli. Johnson, Acad. Nat. Sci. Philadelphia proc., vol. 57, p. 21.

- 1907. Lunatia halli. Weller. Neow Jersey. Geol. Survey Paleontology, vol. 4, p. 677, pl. 76, figs. 11-14 (senonymy and figs. 9,10,15,19, excluded).

- 1916Polinices (Eusipiry) halli Gardner, Marylan Geol. Survey, Upper Cretaceous, p. 409, pl. 13, figs. 1,2 . 
Material: 2 specimens from the lower part of Bekhme Formation (Upper Campanian Masstrichtian) at Bekhme section Northern Iraq.

Gabb (1864) describes this species as follows:

Elongated, subglobose, spire high, whorls five, rounded and angulated above; mouth elliptical; surface, smooth or minutely wrinkled; umbilicus open.

Gabb (1864) provides the following details:

Type locality: New Jersey.

Description: Shell of moderate size, elongated, five whorls regularly increasing in size, evenly inflated, and shouldered posteriorely. The aperture is a little more than one half and body whorl a little more than three- fourths the total altitude. The external surface is smooth excepting for incremental scratches; aperture is semielliptical to ovate.

Occurrence: This species recoded from Ripley Formation, Dave weeks place on Coon Greek, Mcnairy County, Teen and New in Monmouth Formation, (Upper Cretaceous) (Bruce, 1920).

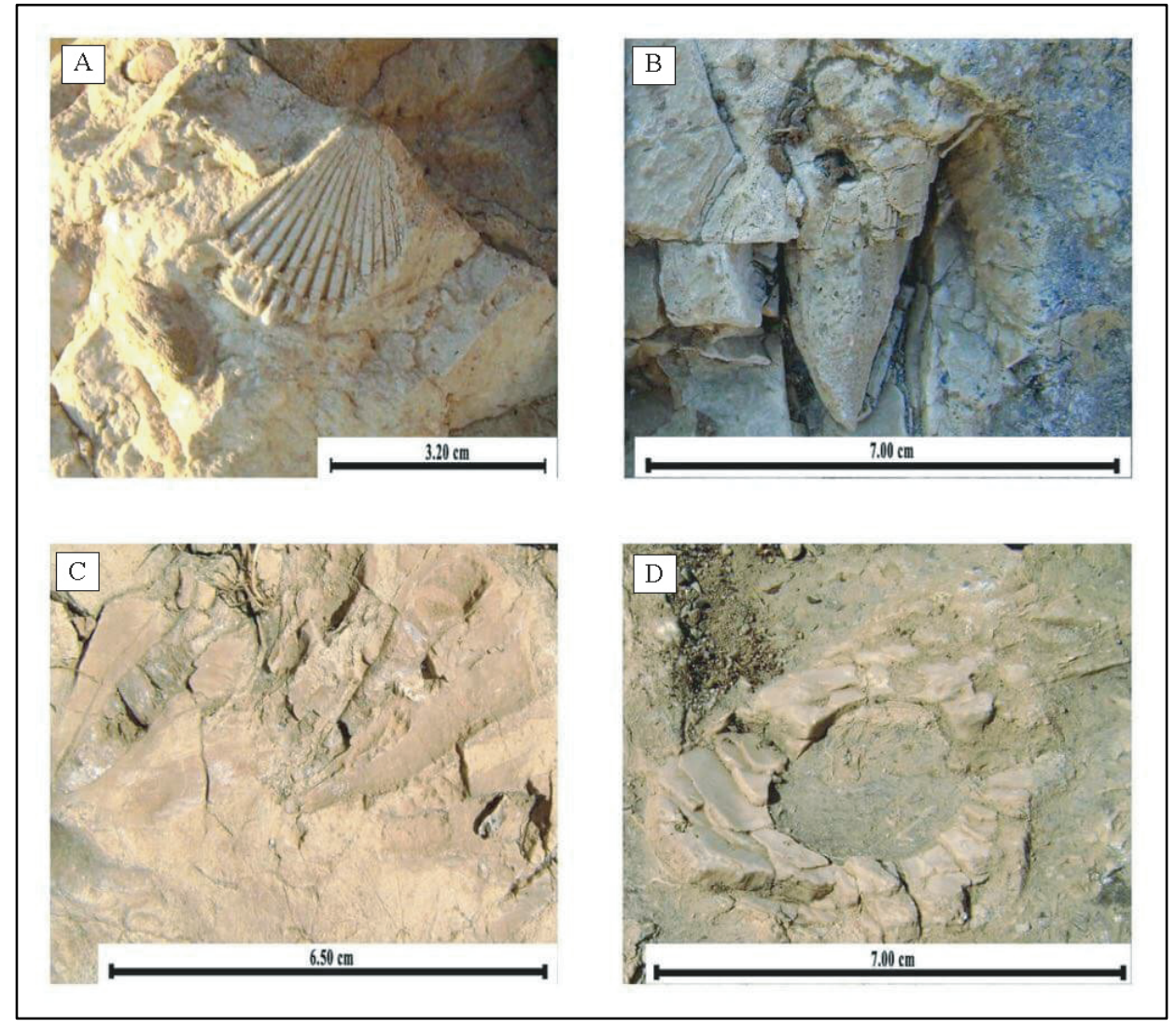

Plate 2. A-Brachiopoda. B and C-Hippurite, sp. D-Durania carnupastoris 
Table 2. Dimension (in cm) of Polinices (Euspira) halli

\begin{tabular}{|l|l|l|l|l|l|l|l|l|l|l|}
\hline $\mathrm{n} .2$ & $\mathrm{H}$ & $\mathrm{D}$ & $\mathrm{HL}$ & $\mathrm{HA}$ & $\mathrm{WA}$ & $\mathrm{PA}^{\circ}$ & $\mathrm{NW}$ & $\mathrm{D} / \mathrm{H}$ & $\mathrm{HL} / \mathrm{H}$ & $\mathrm{WA} / \mathrm{HA}$ \\
\hline Rang & $1.5-2$ & $0.3-1.3$ & $0.5-1$ & $0.4-0.8$ & $0.3-0.7$ & $45-55$ & $4-5$ & $0.2-0.65$ & $0.33-0.5$ & $0.75-0.87$ \\
\hline Mean & 1.75 & 0.8 & 0.75 & 0.5 & 0.5 & 50 & 4.5 & 0.42 & 0.41 & 0.81 \\
\hline
\end{tabular}

Clade Caenogastropoda Cox 1960

Superfamily Ceritlhiodea Fleming, 1822

Family: Turritellidae Clark, 1851

Genus: Turritella Lamarek., 1799

Turritella (Torquesia) figarri Quaas, 1902

(Plate.3; Figs. D and E; Table- 3)

1902 Turritella (Zaria) figarri n. sp Quass: 255, pl. 26, figs. 15- 16.

1963 Turritella (Torquesia) figarri Quass- Abbass: 32, pl. 2, figs. 1-2.

Material: 2 specimens from the Bekhme Formation (Upper Campanian- Masstrichtian) at Bekhme section Northern Iraq.

Description: The specimens have acute spire with spiral angle about 15. The whorls are convex with thin and smooth spiral lines. The aperture is ovoid and small and the suture is depressed.

Remarks: The species closely resembles Turritella (Torquesia) figarri Quass, 1902 from the Campanian- Masstrichtian of the Egyptian and from Aruma Formation (CampanianMasstrichtian) central Saudi Arabia (Mohamed G. and Abdelbaset. S. 2015).

Table 3. Dimension (in cm) of Turritella (Torquesia) figarri

\begin{tabular}{|l|l|l|l|l|l|l|l|l|l|l|}
\hline n.2 & $\mathrm{H}$ & $\mathrm{D}$ & $\mathrm{HL}$ & $\mathrm{HA}$ & $\mathrm{WA}$ & $\mathrm{PA}^{\circ}$ & $\mathrm{NW}$ & $\mathrm{D} / \mathrm{H}$ & $\mathrm{HL} / \mathrm{H}$ & $\mathrm{WA} / \mathrm{HA}$ \\
\hline Rang & $3.2-4$ & $1.2-2$ & $1-1.2$ & $0.4-0.8$ & $0.5-1$ & $30-35$ & $4-5$ & $0.37-0.5$ & $0.31-0.3$ & $1.25-1.25$ \\
\hline Mean & 1.8 & 0.7 & 1.1 & 0.6 & 0.75 & 32.5 & 4.5 & 0.43 & 0.30 & 1.25 \\
\hline
\end{tabular}




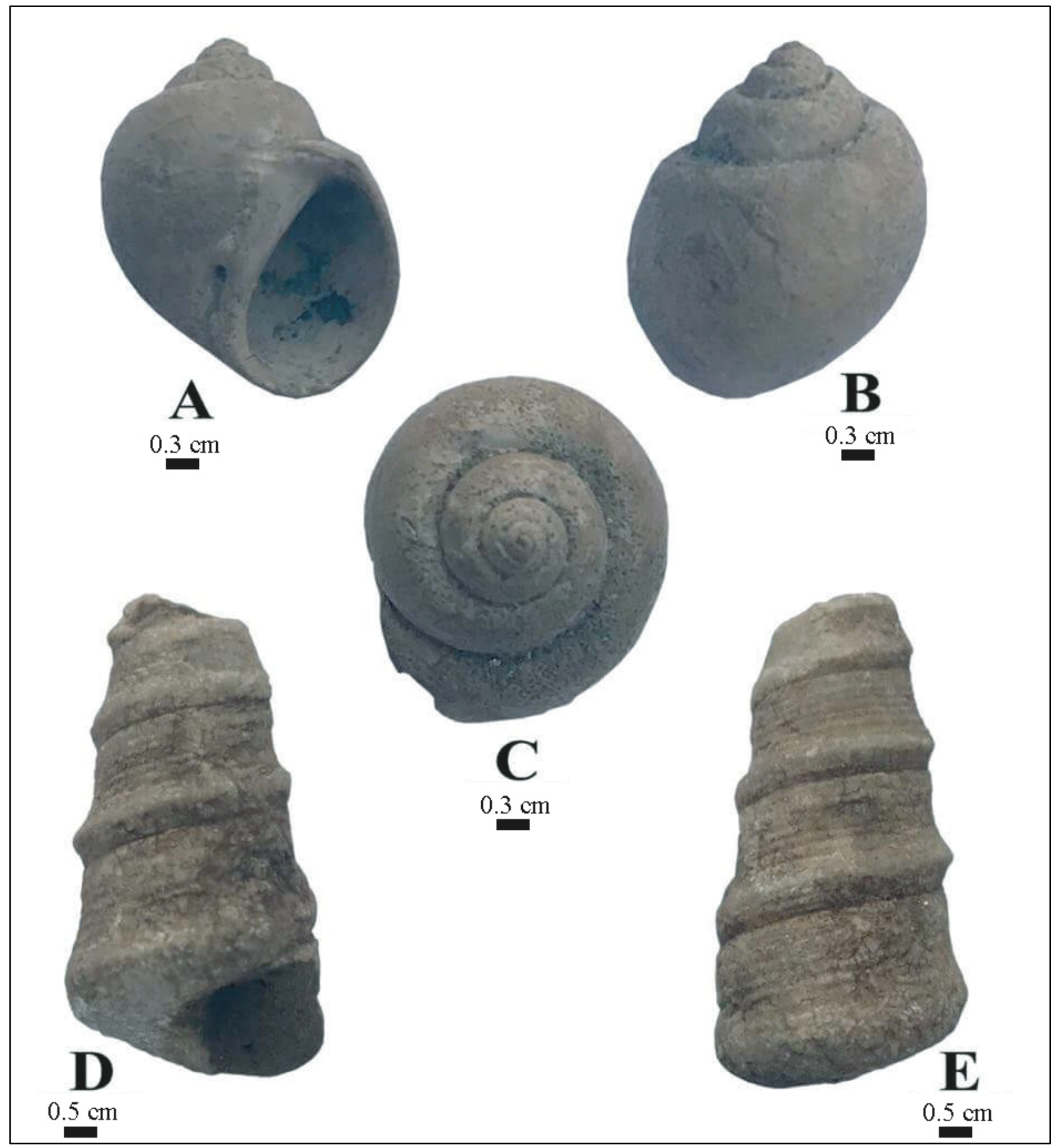

Plate 3. A-C: Polinices (Euspira) halli. A and B: Apertural and apertural view. C: Apical view. D-E: internal moulds of Turritella (Torquesia) figarri Quass showing aperture and apertural view 
Superfamily Acteonoideadorbigny, 1843

Family Acteonoellidae Gill, 1871

Subfamily Iteriinae Cossmann, 1972

Genus Sagdianella Djalilov, 1972

Remarks: Sogdianella is identified by Djalilov (1972) within Actonellidae. Kollmann and Sohl (1979: A4) recorded the genus Sagdianella, which is closely similar to genus Peruviella Olsson, 1944 but differs from Actonella dorbigny 1842, and therefore reclassify it to the Itieriidae in the Superfamily Nerinaecea. Bouchert and Rocroi (2005) considered the Itieriidae as a subfamily of the Acteonellidae. The genus Peruviella is characterized by wide whorls with a longer anterior canal then Sogdianella and the columella exhibits a wide hollow space between the central pillar and columellar lip of the following whorls. The genus Actaeonella is characterized convex sides, the whorls are broader interiorly than in Sogdianella, and the columella has more or less parallel sides and is solid. Sagdianella differ from Actaeonella in the posterior extension of the aperture being twisted antispirally (Ayoub Hannaa and Fursich, 2011).

Kollmann and Sohl (1979: A9 and 1980 report p. 3) and Squires and Sohl (2002: 47) pointed out that the genus Sogdianella characterized by a sharp base of the body whorl, narrow and many whorls that broaden in the lower part of the shell), and a columella which makes an angle with the axis at the lower end and include three folds. The age of Sogdianella ranges from Albian to the Upper Cretaceous and is defined only from central Europe the Middle East, and Transcaucasia (Kohlmann \&Sohl 1979: A11 in Ayoub Hannaa and Fursich., 2011). This genus recorded from lower Turonian of Egypt and North Africa. This is the first record of the genus from Upper Campanian- Masstrichtian of Iraq.

Sogdianella? Laevis laevi (J. de. C Sowerby, 1835) (Plate.4, Figs. A and B)

1835 Volvaria laevis sp. nov. J. de. C. Sowerby in Sedgwick \& Murchison pl. 39, fig. 33.

? 1845 Actaeonella laevis Sowerby- Reuss: 50, pl. 1, fig. 21a, b.

1865 Volvulina laevis Sowerby- Stoliczk: 39.

? 1902 Actaeonella laevis Sowcrby- Choffat: 110, pl. 1, figs. 6,7.

1965 Actaeonella laevis laevis(Sowerby)- Kolmann: 247, pl.1, figs. 5- 8; pl.4, fig. 23.

2011 Sogdianella? Laevis (J.de C.Sowerby, 1835) Ayoub-Hannaa and Fursich:141,Fig.16.

Material: More than 50 specimens are observed on the lower and middle part of the $\mathrm{U}$. Campanian- Masstrichtian Beckhme Formation at the studied section. 
Description: Moderately large- sized $2-3 \mathrm{~cm}$ in height, $0.5-1.5 \mathrm{~cm}$ in diameter. The shell cylindrical to subcylindrical, smooth surface, the whorl sides convex. This species have a short columella with three plates. Aperture has not seen.

Occurrence: This species is described from Upper Cenomanian- lower Turonian of Portugal, Czech Repoblic, and the Santonian- Campanian of the eastern Alps, Lower Turonian in Egypt (Ayoub-Hannaa and Fursich, 2011). This is the first record of the species from Iraq.

Discussion: The specimens of the current study strongly resemble Sogdianella laevis laevis as described by Kollmann (1965). S. Syriaca (Conrad, 1852), described by Kollman (1987:50, pl.3, figs, 39, 40) from Cenomanian of Greece, and S. Subcyclindrica Kollmanand Sohl (1979: All, fig. 6a-c) from Masstrichtian of Cuba differ in being larger and in having well developed columellar folds. Actaeonella caucasica grossouvre: Zekel: and A. caucasica caucasia Cosssmann differ from S. laevis laevis in having broader shells with more convex whorl sides, and in being larger (40-70 and 30-65 mm in length, respectively). A. elongate Kollmann resembles $S$. laevislaevis in size but differ in being much closer and in having three well developed plates. The size and columellar folds of $S$. oregonensis from the lower Cenomanian of east- central Oregon figured by Squires and Saul (2002: 47, fig. 1/ 11-15) are similar to the $S$. laevislaevis, but differ only in being wider than S. laevis laevis (Ayoub-Hannaa and Fursich, 2011).

SuperfamiyNerineoidea Zittel, 1873

Family Nerineidea Zittel 1873

(phaneroptyxidaePchelintsev, 1965= FibaloptygmatidaeHacobjan, 1973)

Type genus $=$ Nerinea Deshayes 1827 (1827:535)

Type species Nerinea mosaeDeshayes 1821 (1821:535)

Remarks: Nerineidae shells are variable group of medium to very large, high oviform to broad turiculate, broadly umbilicate to anomphalous. Whorls are high cylindrical to convex, smooth to strongly ornamentation (Kollmann, 2014). Most of nerineids are characterized by the occurrence of internal folds on the columella and outer lip, which may include from one to seven folds. The spiral folds have a different shape and are referred to as parietal (P) columellar (C), labial or labral (L), and basal folds (B) (Barker, 1990). The number, arrangement, and strength of the internal folds are important for generic classification of nerinerids (Ayoub and Fursich, 2011). 


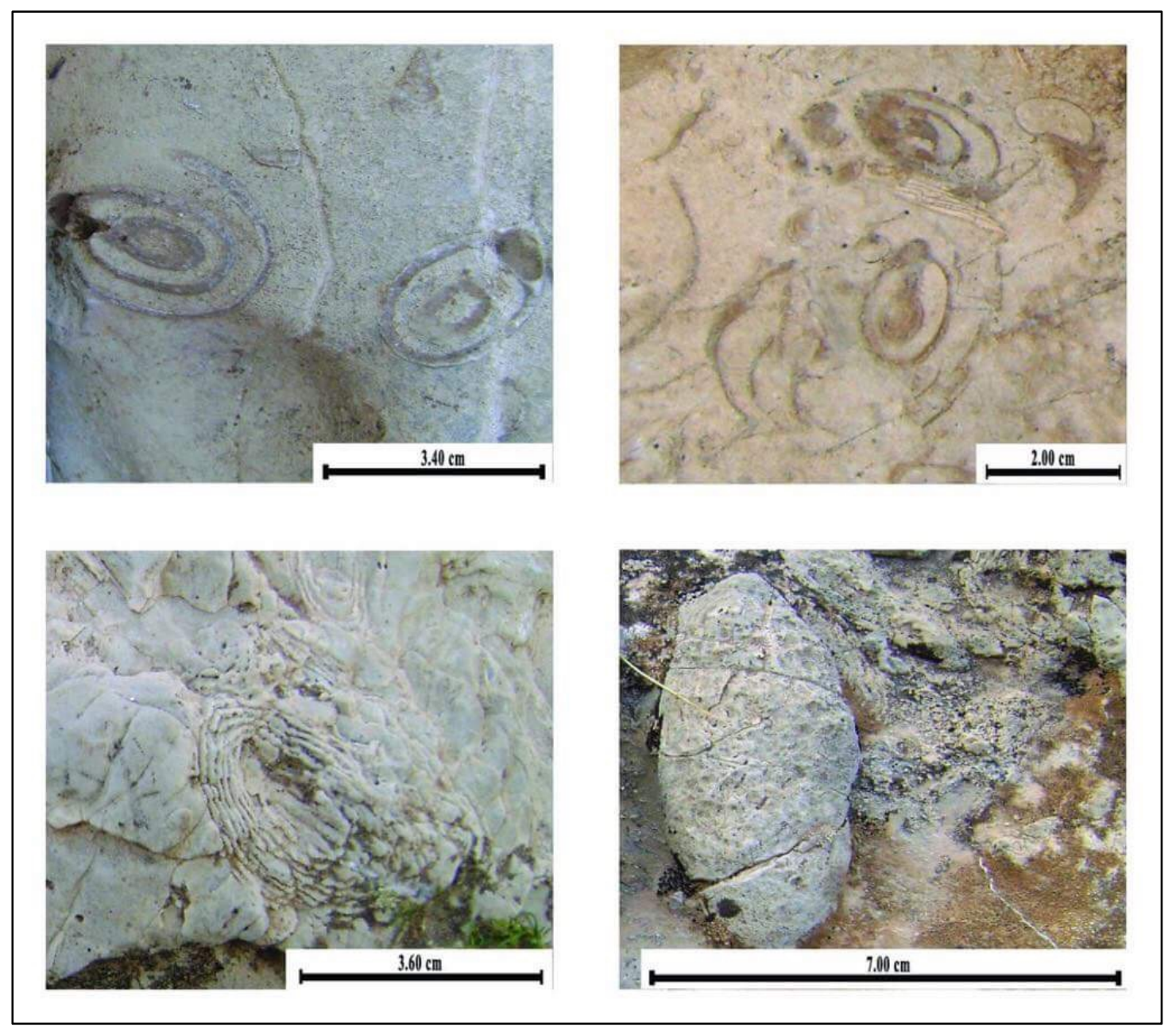

Plate 4. a and b-sogdianella?laevis laevis. $\mathrm{c}$ and d-loftusia elongate

Genus Parasimploptyxix (Munster, 1829)

Parasimploptyxi buchi (Munster, 1829)

(Plt.5, Figs.A-C, Table.4)

2014 Parasimploptyxi buchi (Munster, 1829) Kollmann: 367, Fig.10c.

Material: One internal mould from upper part of Bekhme Formation at Bekhme section, Northern Iraq.

Description: Specimens are large size, turriculate, and high- spired and consist of about 8 overlapping wide whorls with strongly concave surface and raised sutures. Aperture is partly preserved, and apex is commonly damaged. The whorl cross- section displays three simple folds. The parietal fold triangular with rounded base, and labial fold flat with large base, in addition to columellar fold triangular with rounded apex. 
Table 4. Dimension (in cm) of Parasimplotyxis buchi

\begin{tabular}{|c|c|c|c|c|c|}
\hline \multirow{2}{*}{$\mathrm{N}=1$} & $\mathrm{H}$ & $\mathrm{D}$ & $\mathrm{PA}^{\mathrm{o}}$ & $\mathrm{NW}$ & $\mathrm{D} / \mathrm{H}$ \\
\cline { 2 - 6 } & 11 & 5 & $45^{\circ}$ & 8 & 0.45 \\
\hline
\end{tabular}

Occurrence: Late Cretaceous, Abtean (Austria). (Kollmann, 2014)

Superfamily Stombacea Rafinesque, 1815

Family Aporrhaidae Gray, 1850

Genus Anchura Conrad, 1860

Anchura callosa Whiteaves, 1903

(Plate.5, Figs.D and E, Table 5)

1879 Anchura stenoptera Goldfuss:123, pl. 15, figs. 11- 11a. not Rostellaria stenoptera Goldfuss, 1844

1903 Anchura callosa Whiteaves: 358.

1940 Anchura falciformis (Gab). Taff, Hanna, and Cross: 1327, pl.2, figs. 7-9. (Gabb, 1864). 1996 Anchura callosa Whiteanves- Elder \& Saul: 386, figs. 3.5- 3-19.

Material: Two internal moulds from the Middle parts of Bekhme Formation at Bekhme section Northern Iraq.

Diagnosis: See Elder and Saul (1996).

Description: Specimens large, high spired gastropods. The whorls are about eight in number, convex with maximum curvature, and moderately below mid whorl. The body whorl is firmly carinate; deeply thick sutures. Growth line antispirally concave on spire; protoconch damaged. Ornamentation, curved axial ribs are lightly curved concavely to the aperture. Body whorl is relatively large and represents about half of the height of the specimens. Aperture is large and oval with commonly partial outer lip.

Occurrence: This species recorded from Campanian of the North American pacific slope.

Table 5. Dimension (in cm) of Anchura callosa Whiteaves

\begin{tabular}{|l|l|l|l|l|l|l|l|l|l|}
\hline $\mathrm{N}=2$ & $\mathrm{H}$ & $\mathrm{D}$ & $\mathrm{HL}$ & $\mathrm{HA}$ & $\mathrm{NW}$ & $\mathrm{PA}^{\circ}$ & $\mathrm{Nr}$ & $\mathrm{D} / \mathrm{H}$ & $\mathrm{HL} / \mathrm{H}$ \\
\hline Range & $5-5.2$ & $1-1.2$ & $203-2.4$ & $1.4-1.6$ & $6-8$ & $35-40$ & $16-18$ & $0.23-0.24$ & 0.46 \\
\hline Mean & 5.1 & 1.1 & 2.35 & 1.5 & 7 & 37.5 & 17 & 0.23 & 0.46 \\
\hline
\end{tabular}




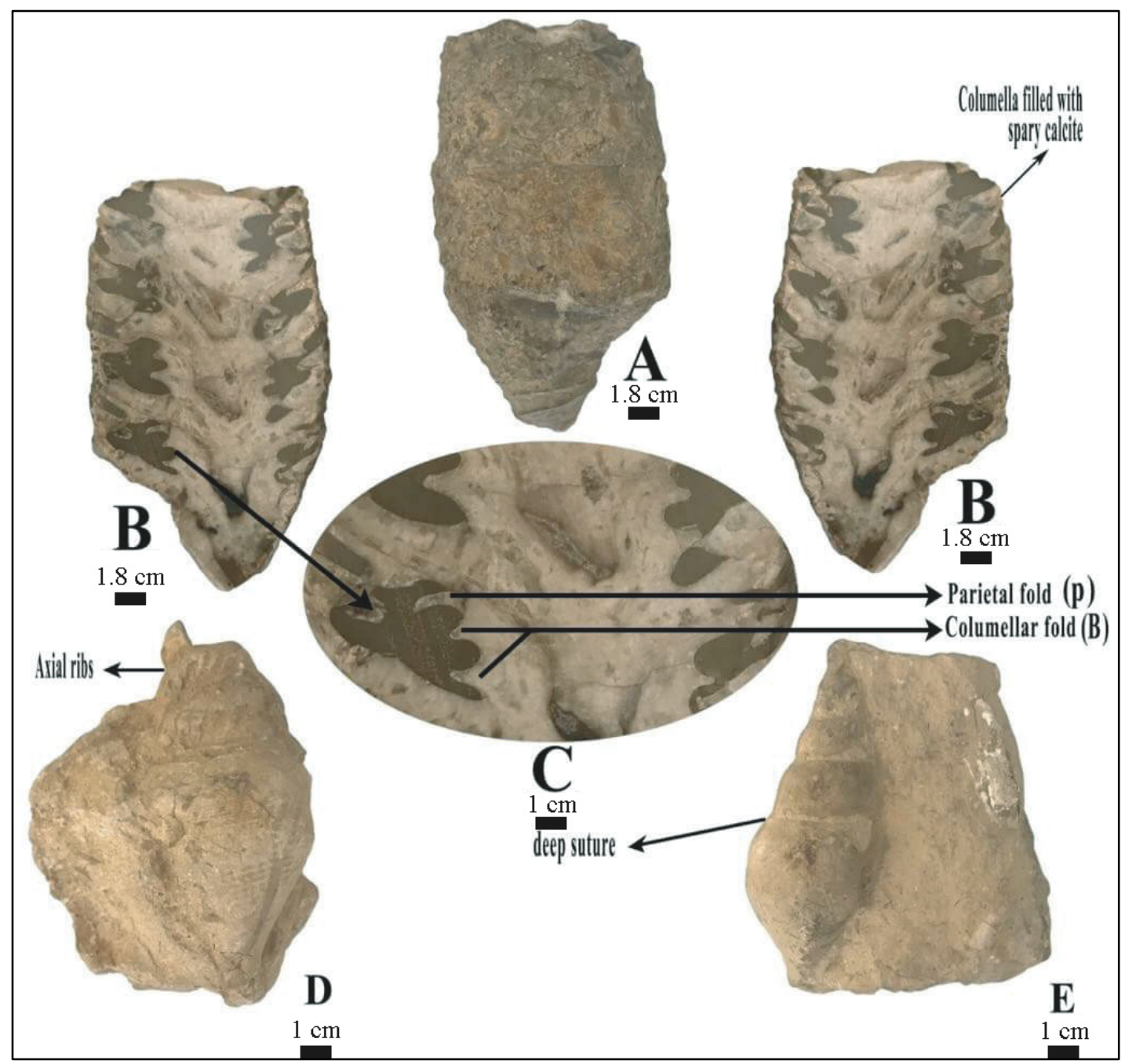

Plate 5. A-C Internal mould of Parasimplotyxi buchi . (A) Apertural view (B-C) Longtudinal whorl section showing the fold pattern \& enclosed characters. D\&E Internal mould of Anchura callosa . (D) Aperrtural view showing the axial ribs. (E) Apertural view

\section{CONCLUSIONS}

1- Six species of Gastropoda belonging to six genera, for families recorded for the first time in Iraq.

2- The species Campanile sp. unnamed because it requires more detail studies for wellpreserved specimens in other localities in Iraq.

3- The age of Campanile sp. is late Campanian- Maastrichtian according to the large forams and rudist associated with it.

4- The six species and specific Campanile sp. Is considered as gastropods- rudist facies because it is associated with different species of rudist. 


\section{REFERENCES}

Abass, H.L., 1963. A Monograph on the Egyption Cretaceous Gastropods. Geologic survey and mineral research department, monographs of the Geological museum, paleontological series 2, 146pp.

Abdul Muniem, A., and Said, V.Y., 1979. Micropaleontlogy large forams of the Cretaceous and Tertiary sediments of Erbil Shaqlawa- Koisinjaq, Raidar area N. Iraq NIMOC. Rep.

Albanesi, C., and Busson G., 1974. Gastropods du cretace Superieur de lextreme- sud tunisien et la region du Tinrhert (Sahara Algerien). Rivista Italian di Paleontologia e Stratigrafia, 80:251-34.

AL-Dulaimi, S.I., and AL-Obaidy, R.A., 2017. Biostratigraphy of Bakhme Formation (Upper Cretaceous) in selected sections Kurdistan region, Northeast Iraq. Iraqi Bulletin of Geology and Mining, 13(1): 1-14.

Al-Karadaghy, A.I., 1989. Microfacies Study of Bekhme Formation in Selected Sections from North and Northeast of Iraq. M.Sc. thesis, University of Salahaddin, $130 \mathrm{pp}$.

Al-Mutwali, M.M., AL-Banna, N.Y. and AL-Ghrear, J.S., 2008. Microfacies and sequence stratigraphy of the Late Campanian Bekhme Formation in the Dohuk area, North Iraq. Geo Arabia, 13(1): 39-54.

AL-Obiday, R.A., 2016. Biostratigraphy and Micrfacies Analysis of Bekhme Formation (Upper Creataceousin selected section Northen Iraq.Unpublished M.Sc.thesis,Baghdad University.

Ameen, B.M. and Karim, K.H. 2008. New Sedimentologic and Stratigraphic characteristics of Upper Boundary of Qamchuqe Formation (early cretaceous) at Northeast of Erbil, Kurdistan region, NE Iraq.

Ayoub, W.H, Fursich, F.T. 2011. Revision of Cenomanian- Turonian (Upper Cretaceous) gastropods from Egypt. An International Journal of Paleontology and Geobiology, 51: 115-153.

Barker, M.J., 1990. The palaeobiology of Nerineacean gastropods. Historical Biology, 3: 249-264.

Bellen, R.C. Van., Dunnington, H.V., Wetzel, R., and Morton, D.M., 1959. Lexique Stratigraphique International, Asia, Iraq int. Geol. Conger. Comm. Stratig, 3(10): 333.

Bolton, C.M.G., 1958. The geology of Rania area, Sit. Inv. Co. Ltd. England. NIMCO unpublished report, 271:118 p.

Bouchet, P., Rocrol, J.P., 2005. Classification nomenclature of gastropod families. Malacologia, 47: 1-39.

Buday, T., and Jassim, S.Z. (ed.), 1980. The Regional Geology of Iraq, Vol. 1: Direct general Geology Surv. \& Miner. Invest., Baghdad 445 pp.

Bruce, W.,1920. The fauna of Rieply Formation on Coon Creek, Tennessee. U.S. Geological survey. Professional paper 137:1-267.

Chatton, M., and Hart, E., 1961. Review of Cenomanian to Masstrichtian stratigraphy in Iraq. IPR/2/14/.62/6298 (unpub. report).

Conrad, T.A., 1860. Description of new species of Cretaceous and Eocene fossils of Mississipi and Albama. Journal of Philadelphia Academy of Natural Sciences, series 2, 4:272-298.

Coss Mann, M., 1906. Essaispaleoconchologie compare' 7. Parise press Universitaires de France, 251 pp.

Cox, LR., 1960. General characteristics of gastropods, In; RC Moor (Ed), Treatise on Invertebrate Paleontology, Part L(Mollusc), Boulder, Geological Society of America, and Lawernce, KS, University of Kanasas press L249L251.

Depely, G., 1939. Les gasteropodes mezozoiques de la region libanaise. Notes memoires de la section d Etudes geologiques du Haut- Commissariat de la Republique Francaiseen syrie et au liban, 3:5- 292.

Dilshad, O.A., 2010. Sedimentology and Stratigraphy of Bekhme Formation (Upper Cretaceous) in selected sections in Kurdistan Region- Iraq. Unpublished M.Sc. thesis. Salahaddin University.

Dunnigton, H.V., 1947. Micropaleontology on samples wl. 2001-2853, from Bekhme Gorge Kurdistan. INOC, NOIR/HV/102. (unpub. R.).

Elder, W.P., and Saul, L.R. 1996. Taxonomy and Biostratigraphy of coniacian Through MasstrichtianAnchura (Gastropoda: Aporrhaiidae) of the North American pacific slope. J. paloont.,70(3): 381-399.

Gabb, W.M., 1864. Description of Cretaceous fossils. California Geological Survey, Palaeontology, 1:57-243, plates 9-32, 1865.

Gary, J.E., 1850. Systematic arrangement of the figures, p. 63-124. In M. E. Gary, Figures of molluscous animals selected from various author; etched fro the use of students. Long, Brown, etc., London, 4: 219.

Goldfuss, G.A.,1826-1844.PetrefactaGermaniae \& C. Petrefacta Museiuniversitatis. Aggildungen und Beschreibungen der Petrefacten Deutschlands und der angrenzenden Lander. herausgegeben von A. Goldfuss. Dusseldorf.

Houbrick, R.S. 1981. Anatomy, biology and systematics of Campanile symbolicum with reference to adaptive radiation of the Cerilhiacea (Gastropoda prosobranchia) Malacologia, 21: 263-289.

Houbrick, R.S., 1989. Campanile revisited: Implications for Cerithiacea (Gastropoda- Prosobranchia). Malacologiazl, 263-289.

Jassim, S.Z., and Goff, J.C., 2006. Geologic of Iraq. Published by Dolin, Prague and Moravian Museum Srn., 341pp. 
Kiel, S., Bandel, K., Banjac, N., Perrilliat, M.C., 2000. On Cretaceous Campanilidae (Caenogostropoda Mollusca) Freiberger Forschung sheft, C490: 15-26.

Kiel, S., 2002. Notes on biogeographic of Campanian- Masstrichtian gastropods. In: WAGREICH.M. (Ed.): Aspects of Cretaceous stratigraphy and palaeobiogeog Osterr. Akad. Wiss., Schriftenr. Erdwiss. Kom,15:109-127.

Kollmann, H.A., 1965. Actaeonellen (Gastropod) aus der ostalpinen oberkreide. Annalen der Naturhistorischen Museums, Wien, 68: 243-262.

Kollmann, H.A. 1978. GastropodenausLosensteinerSchichten der Umgebung Von Losenstein (Oberosterreich).2. Teil: Naticidae, cotombellinidae, Aporrhaidae, Ceritellidae, Epitoniidue. (Mesogustropoda) Annalen des Naturhistorischen Museums, Wien, 81: 173-201.

Kollmann, H.A., 1979. Gastropodenaus LosensteinerSchichten der Umge bung Von Losen stein. 3. Teil: Cerithiacea (Mesogastropoda). Annalen des Naturbiostorischen Museums wien, 82: 11-51.

Kollmann, H.A., Sohl, N.F., 1979. Western hemisphere. Cretaceous 1tieriidae gastropods Geological survey of United states, professional paper 1125 A, A1-15.

Kollmann, H.A. 1985. Upper Cretaceous from excavations from highways Alo (charent, France) Cretaceous Research 6, 85-111.

Kollmann, H.A., 1987. Eine cenoman Gastropod- enfunaaus Nea Nikopolis bei kozani (Mazedonien, Griechenland). Aunalen des Natarhistorischen museums, wien, 89: 37-56.

Kollmann, H.A., 2014. The extinct Nerineoidea and Actonellidea (Heterbranchia, Gastropoda): a palaeobiological approach. Geodiversitas, 36 (3): 349-383.

Lamark, J., 1804. Suite des memoires sur les fossils des environs de paris. Annales du Museum national d'histoire naturelle, 3:436-441.

Mathias, H., Izzet, H., Jean, M., 2012. Thanetian gastropods from the Mesopotamian high folded zone in Northern Iraq.

Matsubara, T., 2009. Achecklist of species- group name of Cenozoic Campanile (Gastropoda: Campanilidae) Paleontological Research, 13: 285- 292.

Mohamed, G., and Abdelbaset, S., and El-Sorogy., 2015. Gastropods from the Campanian- Masstrichtian Aruma Formation, Central Saudi Arabia. Journal of African Earth Science, 128-139.

Quass, A., 1902. Beitrag zur kenntniss der fauna der abersten kreidebidungen in der libyschenwuste (Over wegischichten und Blatterthon). Palaeontographic, 30: 153-336.

Rafinesque, C.S. 1815. Annlyses de la nature ou tableau de l'universe et des crops organises. Palermo, 224 pp.

Saul, L.R, Squires, R.L., 2002. Added nerineoid gastropod evidence from a warm Turonian sea in Southern California. Journal of paleontology, 76: 386- 390.

Sissakian, V.K., and Youkhani, R.Y., 1979. Report in regional Geology mapping of Arbil- Shaqlawa- KoisanjaqRaider area. GEOSURV. Lib. No.975. Baghdad.

Sissakian, V.K., 1997. Geological map of Iraq. $1^{\text {st }}$ edi., scale 1:250000. GEOSURV. Baghdad Iraq.

Squires, R.L., and Saul, L.R. 2002. New early Late Cretaceous (Cenomanian) mollusks from east central Oregon California. Journal of Paleontology, 77: 50-63.

Wenz, W., 1938-1944. Teil 1: Allgemeiner Teil und prosobranchia. In: OH Schindewolf (Ed). Handbuch der palaozologie, Band 6, Gastropoda Berlin, Borntraeger, 1639pp.

Whiteaves, J.F., 1903. On some additional fossils from the Vancouver Cretaceous, with revised list of species thereform. Canada Geological survey, Mesozoic fossils, I (5): 309- 415.

Yassin, M.J., 1973. Analysis and determination of Upper Cretaceous rocks, Southwestern of Halwa Nassara N Iraq. GEOSERV. L.b. no. 607. Baghdad (unpub. report).

Yin, H.F., Yocheison, E.L., 1983. Middle Triassic Gastropodas from Qingyn, Guizhou province, china: 1Pleurotomarias and Murchisoniacea Journal of Paleontology, 57: 162-187. 